\title{
Udział organizacji pożytku publicznego w podatku dochodowym od osób fizycznych - zagadnienia prawno-finansowe
}

\section{Participation of Public Benefit Organizations in Income Tax - Financial and Legal Issues}

Streszczenie. Celem artykułu jest analiza prawna udziału organizacji pożytku publicznego w podatku dochodowym od osób fizycznych. Autor definiuje organizacje pożytku publicznego, wskazując na warunki, które muszą spełnić, aby móc partycypować w podatku dochodowym od osób fizycznych. Najobszerniejsze rozważania dotyczą analizy konstrukcji prawnej instytucji 1\%, jej zakresu przedmiotowego oraz procedury transferu środków z budżetu państwa na rzecz podmiotów uprawnionych. Artykuł przedstawia również skalę omawianego zagadnienia na tle praktycznego funkcjonowania finansów publicznych. Tekst podsumowują rozważania na temat racjonalności oraz istoty przekazywania środków publicznych na rzecz podmiotów prowadzących działalność pożytku publicznego.

Słowa kluczowe: podatek dochodowy od osób fizycznych; organizacje pozarządowe; organizacje pożytku publicznego. 


\begin{abstract}
The purpose of the article is a legal analysis of the participation of public benefit organizations in personal income tax. The author defines public benefit organizations, indicating the conditions that they need to meet in order to be able to participate in the personal income tax. Broad considerations relate to the analysis of the legal structure of the $1 \%$ tax deduction, its scope and the procedures for transfer of funds from the State budget to eligible entities. The article also presents the scale of the issues against the background of the practical functioning of the public finances. The article summarizes the reflection on the rationality and the essence of the transfer of public funds to public benefit organizations.
\end{abstract}

Keywords: public benefit organizations; personal income tax.

\title{
1. Wprowadzenie
}

Na podstawie przepisów ustawy z dnia 24 kwietnia 2003 r. o działalności

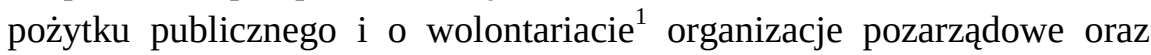
inne podmioty prowadzące działalność pożytku publicznego mogą od 1 stycznia 2004 r. uzyskiwać szczególny status organizacji pożytku publicznego. Konsekwencją uzyskania takowego statusu są określone uprawnienia, ale też i obowiązki. Jednym z przywilejów organizacji posiadających status organizacji pożytku publicznego jest możliwość uzyskiwania przychodów w postaci udziału w podatku dochodowym od osób fizycznych. Podatnik podatku dochodowego od osób fizycznych może, na zasadach i w trybie określonym w przepisach prawa podatkowego, przekazać jeden procent należnego podatku na rzecz wybranych przez siebie organizacji pożytku publicznego. Podatek dochodowy od osób fizycznych jest jednym ze źródeł przychodów państwa oraz jednostek samorządu terytorialnego. Wolą ustawodawcy krąg beneficjentów podatku został poszerzony o organizacje pożytku publicznego. W konsekwencji przychód podatkowy przysługujący stronie publicznej został uszczuplony, choć zgodnie z ogólnymi zasadami prawa finansowego stanowić powinien

Ustawa z dnia 24 kwietnia 2003 r. o działalności pożytku publicznego i o wolontariacie (tekst jedn. Dz.U. z 2010 r. Nr 234 poz. 1536 ze zm.), dalej: u.d.p.p.w. 
dochód budżetowy - a więc taki, który podlega decyzji politycznej parlamentu oraz organów samorządowych.

Celem niniejszych rozważań jest analiza de lege lata udziału organizacji pożytku publicznego w podatku dochodowym od osób fizycznych, określanego mianem instytucji 1\%, a także przedstawienie konstrukcji prawnej i procedury przekazywania podatku oraz ocena ratio legis przedmiotowego zagadnienia.

\section{Organizacja pożytku publicznego}

Organizację pożytku publicznego można określić jako kwalifikowaną formę organizacji pozarządowej o określonym kształcie ustrojowym, wyposażoną w przywileje o charakterze prawno-finansowym, powoływaną dla realizacji zadań społecznie-użytecznych mających walor niekomercyjny i publiczny. Analizowana u.d.p.p.w. stanowi, iż organizacjami pożytku publicznego mogą być organizacje pozarządowe, spółki kapitałowe i kluby sportowe o charakterze non profit oraz podmioty działające na podstawie przepisów o stosunku Państwa do Kościoła Katolickiego, o stosunku Państwa do innych kościołów i związków wyznaniowych oraz ustawy o gwarancjach wolności sumienia i wyznania, jeżeli spełniają określone wymagania w zakresie:

- $\quad$ prowadzenia działalności pożytku publicznego na rzecz ogółu społeczności lub określonej grupy podmiotów wyodrębnionych ze względu na szczególnie trudną sytuację życiową lub materialną;

- ograniczenia lub wyłączenia możliwości prowadzenia działalność gospodarczej;

- $\quad$ przeznaczania zysku na cele pożytku publicznego;

- $\quad$ posiadania statutowego organu kontroli lub nadzoru²;

2 Zgodnie $\mathrm{z}$ art. 20 ust. 1 pkt. 4 u.d.p.p.w. członkowie organu kontroli lub nadzoru nie mogą być członkami organu zarządzającego ani pozostawać z nimi w związku małżeńskim, we wspólnym pożyciu, w stosunku pokrewieństwa, powinowactwa lub podległości służbowej, nie mogą być skazani prawomocnym wyrokiem za przestępstwo umyślne ścigane z oskarżenia publicznego lub przestępstwo skarbowe, mogą otrzymywać $\mathrm{z}$ tytułu pełnienia funkcji w takim organie zwrot uzasadnionych kosztów lub wynagrodzenie w wysokości nie wyższej niż przeciętne miesięczne wynagrodzenie 
- zakazu zasiadania w organie zarządzającym osób skazanych prawomocnym wyrokiem za przestępstwo umyślne ścigane $\mathrm{z}$ oskarżenia publicznego lub przestępstwo skarbowe;

- ustanowienia w statucie organizacji określonych zakazów co do majątku organizacji ${ }^{3}$.

Status organizacji pożytku publicznego przyznaje sąd rejestrowy poprzez wpis do Krajowego Rejestru Sądowego. Wpis ma charakter konstytutywny i dokonywany jest w rejestrze stowarzyszeń, innych organizacji społecznych i zawodowych, fundacji oraz publicznych zakładów opieki zdrowotnej. Organizacja pozarządowa oraz pozostałe podmioty uprawnione mogą uzyskać status organizacji pożytku publicznego pod warunkiem prowadzenie działalności o charakterze pożytku publicznego przez okres co najmniej 2 lat.

Nie wszystkie podmioty posiadające status organizacji pożytku publicznego mogą otrzymywać wpłaty będące częścią podatku należnego od podatników, prawodawca bowiem przywilej ten zastrzegł wyłącznie dla organizacji pożytku publicznego, które spełniają następujące warunki ${ }^{4}$ :

- znajdują się w wykazie organizacji mających status organizacji pożytku publicznego ogłoszonym, w drodze obwieszczenia, w Dzienniku Urzędowym Rzeczypospolitej Polskiej „Monitor Polski”;

- mają konto bankowe.

W wykazie ogłaszanym jako obwieszczenie ministra właściwego do spraw zabezpieczenia społecznego znajdują się te spośród organizacji pożytku publicznego, które spełniają dwie przesłanki:

- zamieściły na stronie internetowej urzędu obsługującego ministra właściwego do spraw zabezpieczenia społecznego sprawozdanie merytoryczne ze swojej działalności oraz sprawozdanie finansowe;

w sektorze przedsiębiorstw ogłoszone przez Prezesa Głównego Urzędu Statystycznego za rok poprzedni.

3 Szerzej: A. Ceglarski, Organizacje pożytku publicznego, Warszawa 2005 r., s. 25-55; M.H. Kurleto, Organizacje pozarzq̨dowe w działalności pożytku publicznego, Warszawa 2008, s. 61-65.

4 Art. 27a u.d.p.p.w, art. 45a ust. 1 ustawy z dnia 26 lipca 1991 r. o podatku dochodowym od osób fizycznych (tekst jedn. Dz.U. z 2012 r., poz. 361 ze zm.). 
- nie mają we wpisie do Krajowego Rejestru Sądowego informacji o otwarciu likwidacji lub ogłoszeniu upadłości organizacji.

Wykaz organizacji posiadających status organizacji pożytku publicznego prowadzi minister właściwy do spraw zabezpieczenia społecznego. Jest on prowadzony w formie elektronicznej i zamieszczany na stronie internetowej Biuletynu Informacji Publicznej nie później niż do 15 grudnia roku każdego podatkowego. Wykaz zawiera w odniesieniu do każdej organizacji pożytku publicznego jej nazwę i siedzibę, numer wpisu do Krajowego Rejestru Sądowego oraz numer rachunku bankowego właściwego do przekazania $1 \%$ podatku 5 .

\section{Elementy konstrukcji prawnej}

Pierwsze rozwiązania systemowe pozwalające na przekazywanie przez podatników części podatku należnego fiskusowi zostały wprowadzone w okresie po II wojnie światowej we Włoszech i Hiszpanii i dotyczyły możliwości przekazania $1 \%$ podatku należnego na rzecz kościołów ${ }^{6}$. Prekursorem w rozszerzeniu alokacji $1 \%$ podatku na rzecz organizacji pozarządowych stały się Węgry, gdzie w 1996 roku uchwalono ustawę „o wykorzystaniu określonej części podatku dochodowego od osób fizycznych”, która pozwala na przekazywanie 1\% podatku należnego na rzecz kościołów, organizacji pozarządowych prowadzących działalność pożytku publicznego oraz na rzecz tzw. organizacji quasi-pozarządowych ${ }^{7}$. W latach następnych podobne regulacje prawne zostały uchwalone w Słowacji (2000), na Litwie (2002) i w Rumunii (2003) ${ }^{8}$.

\footnotetext{
Art. 27a u.d.p.p.w.

J. Kopyra, Ustawa o działalności pożytku publicznego i wolontariacie. Komentarz, Warszawa 2005, s. 116.

7 M. Arczewska, Test na filantropię, czyli 1\% w polskim wykonaniu, „Trzeci Sektor” 2006, nr 7, s. 44.

8 K. Hadzi-Miceva, Prawne i instytucjonalne mechanizmy współpracy organizacji pozarzq̨dowych i administracji państwowej w Chorwacji, Estonii i na Węgrzech [w:] M. Rymsza (red.) Organizacje pozarzq̨dowe. Dialog Obywatelski. Polityka Państwa, Warszawa 2008, s. 36.
} 
W Polsce na wzór wymienionych państw w art. 27 u.d.p.p.w. wprowadzono zasadę, zgodnie z którą podatnik podatku dochodowego od osób fizycznych może, na zasadach i w trybie określonym w przepisach odrębnych, przekazać $1 \%$ podatku obliczonego zgodnie z odrębnymi przepisami na rzecz wybranej przez siebie organizacji pożytku publicznego. Wskazana norma ustanawiająca instytucję 1\% ma charakter bardzo ogólnikowy, zawiera odesłanie do odrębnych przepisów podatkowych w zakresie zasad i trybu przekazywania 1\% podatku. Takie rozwiązanie świadczy o woli ustawodawcy regulowania wszelkich zagadnień skorelowanych z podatkami w ustawach podatkowych. Stąd też szczegółowe określenie reguł przekazywania podatku od osób fizycznych na rzecz organizacji pożytku publicznego zostało ustanowione w ustawie o podatku dochodowym od osób fizycznych oraz w ustawie z dnia 20 listopada 1998 r. o zryczałtowanym podatku dochodowym od niektórych przychodów osiąganych przez osoby fizyczne ${ }^{9}$. Ustawa o działalności pożytku publicznego wyznacza jedynie ogólne ramy przedmiotowej konstrukcji, określając kategorię podatników uprawnionych do przekazania części podatku należnego, jego wysokość określoną procentowo oraz rodzaj podmiotów będących beneficjentami, rozwinięcie tych elementów konstrukcji znajduje się w ustawach podatkowych.

Podmiotami uprawnionymi do przekazywania 1\% podatku należnego zgodnie z zasadą zawartą w u.d.p.p.w. są podatnicy podatku dochodowego od osób fizycznych. Niemniej z uwagi na ogólny charakter tej ustawy powstaje pytanie, czy wskazane uprawnienie przysługuje wszystkim podatnikom podatku dochodowego od osób fizycznych bez względu na rodzaj osiąganych dochodów (przychodów) podlegających opodatkowaniu?

Przedmiotową analizę należy rozpocząć od ustalenia zakresu podmiotowego podatników uprawnionych do przekazywania 1\% podatku. Zakres ten wyznaczają przepisy ustawy o podatku dochodowym od osób fizycznych oraz ustawy o zryczałtowanym podatku dochodowym od niektórych przychodów osiąganych przez osoby fizyczne. Wskazane akty norma-

9 Ustawa z dnia 20 listopada 1998 r. o zryczałtowanym podatku dochodowym od niektórych przychodów osiąganych przez osoby fizyczne (Dz.U. z 1998 r. Nr 144, poz. 930 ze. zm.). 
tywne zwierają ogólne wskazanie na to, iż prawem przekazania 1\% podatku dysponować mogą podatnicy składający zeznanie podatkowe ${ }^{10}$.

Podział podatników podatku dochodowego od osób fizycznych można więc przeprowadzić w oparciu o rodzaj zeznania podatkowego o wysokości osiągniętego dochodu (poniesionej straty) w roku podatkowym, jakie podatnicy są obowiązani składać urzędom skarbowym. Zgodnie z delegacją ustawową zawartą w art. 45b ustawy o podatku dochodowym od osób fizycznych Minister Finansów rozporządzeniem z dnia 10 października 2013 r. w sprawie określenia wzorów rocznego obliczenia podatku oraz zeznań podatkowych obowiązujących w zakresie podatku dochodowego od osób fizycznych ${ }^{11}$ określił wzory zeznań o wysokości osiągniętego dochodu. Wzory te, stanowiące załączniki do rozporządzenia, mają zastosowanie do przedstawienia uzyskanych dochodów lub poniesionych strat od 1 stycznia 2013 roku. W myśl tego rozporządzania podatnicy podatku dochodowego od osób fizycznych składają zeznania na następujących wzorach:

PIT-36 - właściwy dla podatników, którzy uzyskali przychody (dochody) opodatkowane na ogólnych zasadach przy zastosowaniu skali podatkowej i nie wypełniają zeznania PIT-37, gdyż osiągnięte przez nich dochody (poniesione straty) nie mieszczą się w zakresie tego zeznania; formularz ten składają przede wszystkim podatnicy, którzy prowadzili pozarolniczą działalność gospodarczą opodatkowaną według skali podatkowej, a także uzyskali dochody z zagranicy;

PIT-36L - składają go podatnicy, którzy osiągnęli dochody z pozarolniczej działalności gospodarczej lub działów specjalnych produkcji rolnej na zasadach określonych w art. 30c;

PIT-37 - obowiązuje podatników, którzy uzyskali przychody opodatkowane na ogólnych zasadach według skali podatkowej wyłącznie ze źródeł położonych na terytorium RP, za pośrednictwem płatników i nie prowadzili pozarolniczej działalności gospodarczej opodatkowanej na

\footnotetext{
10 Art. 45c ustawy o podatku dochodowym od osób fizycznych oraz art. 21b ust. 1 ustawy o zryczałtowanym podatku dochodowym od niektórych przychodów osiąganych przez osoby fizyczne.

11 Dz.U. 2013, poz. 1303.
} 
ogólnych zasadach przy zastosowaniu skali podatkowej oraz działów specjalnych produkcji rolnej;

PIT-38 - właściwy dla podatników, którzy uzyskali przychody z odpłatnego zbycia papierów wartościowych lub pochodnych instrumentów finansowych i innych określonych w art. 30b ustawy;

PIT-39 - przeznaczony dla podatników, którzy uzyskali dochody z odpłatnego zbycia nieruchomości i praw majątkowych, wybudowanych lub nabytych po dniu 31 grudnia 2008 r.;

PIT-40 - składany przez płatników podatku dochodowego od osób fizycznych na wniosek podatnika.

Wskazane powyżej wzorce, odpowiednio w części formularza „P” (PIT-36), „O” (PIT-36L), „I” (PIT-37) oraz „H” (PIT-38 i PIT-39), zawierają wniosek o przekazanie $1 \%$ podatku należnego na rzecz organizacji pożytku publicznego. Z uwagi na to, iż załączniki do aktu normatywnego, którym jest rozporządzenie Ministra Finansów, mają charakter powszechnie obowiązujący, należy uznać, że uprawnienie dysponowania 1\% podatku należnego przysługuje tym podatnikom, którzy na mocy ustawy o podatku dochodowym od osób fizycznych obowiązani są składać urzędom skarbowym zeznanie o wysokości osiągniętego dochodu w roku podatkowym. Uprawnienia takiego są pozbawieni podatnicy, w imieniu których roczne obliczenie podatku od dochodu uzyskanego przez podatnika w roku podatkowym sporządza płatnik, zgodnie z wzorem formularza PIT-40, który nie zawiera wniosku o przekazanie $1 \%$ podatku należnego na rzecz organizacji pożytku publicznego.

Z kolei ustawa o zryczałtowanym podatku dochodowym od niektórych przychodów osiąganych przez osoby fizyczne uprawnienie przekazywania $1 \%$ podatku należnego wynikającego $\mathrm{z}$ zeznania podatkowego przyznaje wyłącznie osobom opodatkowanym ryczałtem od przychodów ewidencjonowanych, tj. takim, które prowadzą działalność gospodarczą w zakresie określonym w art. 6 ustawy i nie spełniają przesłanek określonych w art. 8 ust. 1. Osoby te są zobowiązane do składania zeznań według ustalonego wzoru (PIT-28) o wysokości uzyskanego przychodu, wysokości dokonanych odli- 
czeń i należnego ryczałtu od przychodów ewidencjonowanych, w którym w części „M” mogą dokonać alokacji 1\% podatku należnego ${ }^{12}$.

Uprawnienie do przekazania 1\% należnego podatku nie przysługuje pozostałym podatnikom podatku dochodowego od osób fizycznych, o których mowa w ustawie o zryczałtowanym podatku dochodowym od niektórych przychodów osiąganych przez osoby fizyczne, tj. osobom opodatkowanym w formie karty podatkowej ${ }^{13}$ oraz osobom duchownym opłacającym ryczałt. W stosunku do tych osób wprowadzenie instytucji 1\% jest o tyle utrudnione, iż są one zwolnione z obowiązku składania zeznań podatkowych ${ }^{14}$.

Selektywne potraktowanie podatników podatku dochodowego od osób fizycznych w zakresie przyznania przywileju przeznaczenia 1\% należnego podatku jest wyrazem swobody politycznej ustawodawcy w zakresie określania kierunków wydatkowania danin publicznych. W opinii Trybunału Konstytucyjnego nieuwzględnienie określonych kategorii podatników nie może być traktowane jako odstępstwo od konstytucyjnej zasady równego traktowania (art. 32) bowiem wolność przeznaczania części należnego podatku jest sui generis przywilejem i nie może być traktowana jako wyraz obowiązku ustawodawcy do jego wprowadzania ${ }^{15}$. Pogląd ten zasługuje na akceptację. Brak preferencji dla osób podlegających zryczałtowanym formom opodatkowania (karta podatkowa, duchowni) nie stanowi naruszenia zasady równości, bowiem sama już konstrukcja opodatkowania, korzystna z punktu widzenia wysokości przyszłego zobowiązania podatkowego, i prawo jej wyboru stanowią swojego rodzaju przywilej dla podatnika.

Następnym elementem konstrukcji jednoprocentowego udziału, niezbędnym do określenia wysokości przekazywanych środków finansowych na

12 PIT-28 stanowi załącznik do rozporządzania Ministra Finansów z dnia 12 listopada 2013 r. w sprawie określenia wzorów zeznania, deklaracji i informacji podatkowych obowiązujących w zakresie zryczałtowanego podatku dochodowego od niektórych przychodów osiąganych przez osoby fizyczne (Dz.U. 2013, poz. 1358).

13 Zryczałtowany podatek dochodowy w formie karty podatkowej mogą płacić podatnicy prowadzący działalność określoną w art. 23 ustawy z o zryczałtowanym podatku dochodowym od niektórych przychodów osiąganych przez osoby fizyczne.

14 Art. 24 ust. 1 oraz art. 50 ustawy z o zryczałtowanym podatku dochodowym od niektórych przychodów osiąganych przez osoby fizyczne.

15 Por. wyrok TK z dnia 13 czerwca 2006 r., K 11/05 (Dz.U. z 2006 r. Nr 108, poz. 748). 
rzecz organizacji pożytku publicznego, jest stawka procentowa. Stawka ta jest relacją pomiędzy wielkością alokacji części podatku a wielkością podatku należnego wynikającego z zeznania podatkowego. W świetle ustaw podatkowych stawka została ustanowiona jako procentowa maksymalna granica dokonania przysporzenia na rzecz organizacji pożytku publicznego przez podatnika. Podatnik nie jest związany obowiązkiem wnioskowania o przekazanie kwoty odpowiadającej dokładnie wielkości 1\% podatku należnego, może według własnego uznania przekazać kwotę mniejszą. Ustawodawca do wielkości przekazywanej kwoty zastosował konstrukcję zaokrąglania do pełnych dziesiątek groszy w dół. Takie rozwiązanie pozostaje w sprzeczności z ogólną zasadą zaokrąglania kwot wynikających z zobowiązania podatkowego do pełnych złotych, a pomijania końcówek kwot mniejszych niż 50 gr $^{16}$, jednakże należy przyjąć je za słuszną, bowiem przy niskich kwotach podatku należnego zaokrąglanie w dół do pełnych złotych powodowałoby (w skali makro) znacząco mniejszy przychód organizacji pożytku publicznego, z kolei przyjęcie zasady zaokrąglania do pełnych złotych w górę skutkowałoby przekroczeniem maksymalnej granicy $1 \%$.

\section{Procedura dokonania przysporzenia na rzecz organizacji pożytku publicznego}

Uzyskanie przez organizację pożytku publicznego środków finansowych przypadających z należnego podatku od osób fizycznych uzależnione jest od terminowego złożenia przez podatnika podatku dochodowego od osób fizycznych zeznania podatkowego. Prawodawca wyraźnie zastrzegł, że dotrzymanie terminu jest warunkiem sine qua non przekazania kwoty ${ }^{17}$. W przypadku podatników podatku dochodowego od osób fizycznych opodatkowanych na zasadach ogólnych, a także uzyskujących dochody z kapitałów opodatkowanych oraz pozarolniczej działalności gospodarczej lub działów specjalnych produkcji rolnej, terminem tym jest, co do zasa-

16 Art. 63 ustawy z dnia z dnia 29 sierpnia 1997 r. Ordynacja podatkowa (tekst jedn. Dz.U. z 2012 r., poz. 749 ze zm.).

17 Art. 45c ust. 1 ustawy o podatku dochodowym od osób fizycznych. 
dy, 30 kwietnia roku następującego po roku podatkowym ${ }^{18}$. Dla osób fizycznych opodatkowanych ryczałtem od przychodów ewidencjonowanych zeznanie o wysokości uzyskanego przychodu, wysokości dokonanych odliczeń i należnego ryczałtu od przychodów ewidencjonowanych powinno być złożone w terminie do 31 stycznia następnego roku. W obu przypadkach jeżeli ostatni dzień terminu przypada na sobotę lub dzień ustawowo wolny od pracy, za ostatni dzień terminu uważa się następny dzień po dniu lub dniach wolnych od pracy ${ }^{19}$. Po upływie powyższych terminów uwzględnienie wniosku o przekazanie $1 \%$ należnego podatku na rzecz organizacji pożytku publicznego jest dopuszczalne wyłącznie w drodze korekty złożonego zeznania. Takie rozwiązanie jest możliwe pod warunkiem złożenia zeznania w terminie i dokonania korekty w ciągu dwóch miesięcy od upływu ustawowego terminu dla złożenia zeznania podatkowego $^{20}$. Zeznania podatkowe składane w późniejszym terminie w części dotyczącej wniosku o przekazanie $1 \%$ nie mogą być podstawą do przekazania części należnego podatku na rzecz organizacji pożytku publicznego.

Procedurę przekazania części podatku należnego rozpoczyna wniosek podatnika skierowany do naczelnika urzędu skarbowego. Za wniosek, zgodnie z art. 45c ustawy o podatku dochodowym od osób fizycznych, uważa się wskazanie przez podatnika w zeznaniu podatkowym albo w korekcie zeznania podatkowego numeru wpisu do Krajowego Rejestru Sądowego organizacji pożytku publicznego oraz kwoty do przekazania na rzecz tej organizacji w wysokości nieprzekraczającej $1 \%$ podatku należnego.

Podatnicy w składanym zeznaniu mogą wskazać wyłącznie jedną organizację pożytku publicznego uprawnioną do otrzymania 1\% należnego podatku. Nie oznacza to, iż jeden podatnik może dokonać dyspozycji tylko na rzecz jednej organizacji pożytku publicznego. W sytuacji, gdy podatnik osiągnął dochody z różnych źródeł i jest zobowiązany do złożenia w urzędzie skarbowym dwóch lub więcej odrębnych zeznań (np. PIT-36,

\footnotetext{
Art. 45 ust. 1 i 1a ustawy o podatku dochodowym od osób fizycznych.

Art. $12 \S 5$ ustawy Ordynacja podatkowa.

Art. 45c ust.1 ustawy o podatku dochodowym od osób fizycznych.
} 
PIT-38 i PIT-39), może w każdym ze składanych zeznań wskazać inną organizację pożytku publicznego. Zasada wskazania wyłącznie jednej organizacji pożytku publicznego nie dotyczy więc podatnika, lecz składanego przez niego zeznania podatkowego.

Następstwem poprawnie sformułowanego wniosku w zeznaniu podatnika złożonym w terminie jest powstanie obowiązku organu podatkowego (naczelnika urzędu skarbowego) przekazania na rzecz wskazanej we wniosku organizacji pożytku publicznego wyliczonej kwoty z należnego podatku. Naczelnik urzędu skarbowego jest związany wskazaniem, nie ma on w tym zakresie żadnych kompetencji uznaniowych. Zgodnie z art. 45c ust. 4 ustawy o podatku dochodowym od osób fizycznych przekazuje on kwotę z należnego podatku na rzecz organizacji pożytku publicznego w terminie od maja do lipca roku następującego po roku podatkowym, za który składane jest zeznanie podatkowe, na rachunek bankowy. Przekazywana kwota jest pomniejszana o koszty przelewu bankowego ${ }^{21}$. Ponadto naczelnicy urzędów skarbowych są zobowiązani do przekazywania organizacjom pożytku publicznego pisemnych informacji zawierających: imię i nazwisko, wysokość kwoty oraz adres podatnika, który wnioskował o przekazanie tej organizacji części podatku od uzyskiwanych przez niego dochodów. Informacje są przekazywane jedynie w odniesieniu do tych podatników, którzy w zeznaniu podatkowym lub korekcie zeznania wyrazili zgodę na ujawnienie swoich danych organizacji pożytku publicznego lub wskazali szczegółowy cel przeznaczenia środków.

Stosownie do art. 45c ust. 2 ustawy o podatku dochodowym od osób fizycznych warunkiem przekazania przez naczelnika urzędu skarbowego kwoty określonej w zeznaniu podatkowym na rzecz organizacji pozarządowej jest zapłata w pełnej wysokości podatku należnego stanowiącego podstawę obliczenia tej kwoty. Przy czym zapłata podatku (zaległości podatkowej) powinna nastąpić nie później niż w terminie dwóch miesięcy od upływu terminu dla złożenia zeznania podatkowego ${ }^{22}$. Niezapłacenie

\footnotetext{
21 Zasada ta obowiązuje również $\mathrm{w}$ przypadku przysporzeń od podatników podatku opodatkowanych ryczałtem od przychodów ewidencjonowanych.

22 Art. 45c ust. 5 ustawy o podatku dochodowym od osób fizycznych; nie zmienia to zasady, iż obowiązkiem podatników podatku dochodowego od osób fizycznych rozli-
} 
podatku w pełnej wysokości bądź zapłacenie go w terminie późniejszym niż dwa miesiące po upływie terminu dla złożenia zeznania podatkowego oznaczać będzie, iż pomimo złożonego wniosku w zeznaniu podatkowym o przekazanie części podatku na rzecz organizacji pożytku publicznego, naczelnik urzędu skarbowego nie będzie związany takim wnioskiem i nie przekaże części podatku na rzecz organizacji pożytku publicznego. Wskazana zasada została wprowadzona ustawą z dnia 6 listopada 2008 r. o zmianie ustawy o podatku dochodowym od osób fizycznych, ustawy o podatku dochodowym od osób prawnych oraz niektórych innych ustaw $^{23}$ i ma zastosowanie do przekazywania 1\% należnego podatku od dochodów uzyskiwanych od roku 2008. Wcześniej przepisy ustawy o podatku dochodowym od osób fizycznych zobowiązywały naczelników urzędów skarbowych do przekazywania 1\% podatku należnego bez względu na to, czy podatek został zapłacony. Osoby posiadające zaległości podatkowe mogły więc wnioskować o przekazanie organizacjom pożytku publicznego kwot z ich podatku należnego. Stan taki dla fiskusa był podwójnie niekorzystny. Z jednej strony nie otrzymywał on w wyznaczonym terminie (lub wcale) podatku lub zaliczek na podatek, zaś z drugiej strony zobowiązany był do przekazania środków publicznych, w sytuacji gdy sam ich nie otrzymał.

W obecnie obowiązującym stanie prawnym należy wykluczyć możliwość odliczenia kwoty 1\% podatku należnego wynikającego z zeznania podatkowego $\mathrm{w}$ sytuacji, gdy podatnik samodzielnie dokona wpłaty na konto organizacji pożytku publicznego ${ }^{24}$. Przepisy art. 45c ust. 1 ustawy

czających się na zasadach ogólnych jest zapłata podatku należnego w pełnej wysokości $\mathrm{w}$ terminie do 30 kwietnia roku następującego po roku podatkowym (art. 45 ust. 4 ustawy o podatku dochodowym od osób fizycznych). Podatek niezapłacony w terminie płatności stanowi zaległość podatkową.

Ustawa z dnia 6 listopada 2008 r. o zmianie ustawy o podatku dochodowym od osób fizycznych, ustawy o podatku dochodowym od osób prawnych oraz niektórych innych ustaw (Dz.U. Nr 209, poz. 1316 ze zm.).

24 Obecną regulację przekazywania 1\% wprowadziła ustawa z dnia 16 listopada $2006 \mathrm{r}$. o zmianie ustawy o podatku dochodowym od osób fizycznych oraz o zmianie niektórych innych ustaw (Dz.U. z 2006 r. Nr 217 poz. 1588 ze zm.); według stanu sprzed nowelizacji obowiązywała konstrukcja samodzielnej wpłaty $1 \%$ podatku należnego przez podatników bezpośrednio na rzecz organizacji pożytku publicznego. 
o podatku dochodowym od osób fizycznych oraz art. 21b ust. 1 ustawy o zryczałtowanym podatku dochodowym od niektórych przychodów osiąganych przez osoby fizyczne jednoznacznie stanowią, iż czynność przekazania zastrzeżona jest dla naczelników urzędów skarbowych. Ewentualne wnioskowanie do naczelnika urzędu skarbowego w przedmiocie udzielenia przez niego zgody na samodzielne dokonanie wpłaty przez podatnika na rzecz organizacji pożytku publicznego nie może być pozytywnie rozpatrzone, bowiem przekazanie $1 \%$ stanowi jego ustawowy obowiązek, którego wykonanie może nastąpić wyłącznie przez niego lub przy pomocy kierowanego przez niego urzędu skarbowego. Zatem samodzielna wpłata dokonana przez podatnika bez pośrednictwa naczelnika urzędu skarbowego nie może zostać zakwalifikowana jako przekazanie części podatku należnego, czynność taka na gruncie obowiązujących przepisów będzie darowizną, pomniejszającą podstawę obliczenia podatku podatnika.

\section{Zastosowanie instytucji 1\% w praktyce - skala zjawiska}

Według stanu na 13 września 2013 r. łączna kwota 1\% należnego podatku przekazana na rzecz organizacji pożytku publicznego z rozliczenia za rok podatkowy 2012 r. wyniosła 480,0 mln zł, co stanowiło 0,72\% należnego podatku dochodowego. Zgodnie z informacjami Ministerstwa Finansów podatnicy składający zeznanie:

- $\quad$ PIT-36, PIT-36L i PIT-37 - przekazali 463,4 mln zł, tj. 0,72\% należnego podatku dochodowego obliczonego przy zastosowaniu skali podatkowej oraz według $19 \%$ stawki podatku od dochodów z pozarolniczej działalności gospodarczej lub działów specjalnych produkcji rolnej, zaś średnia przekazana kwota wyniosła 42 zł;

- $\quad$ PIT-38 - przekazali 5,5 mln zł, tj. 0,80\% należnego podatku dochodowego wykazanego w tych zeznaniach, a średnia przekazana kwota wyniosła 52 zł; 
- $\quad$ PIT-28 i PIT-39 - 11,1 mln zł, co stanowiło 0,59\% należnego podatku dochodowego wykazanego w tych zeznaniach, średnia przekazana kwota wyniosła $39 \mathrm{zł}^{25}$.

W wykazie organizacji pożytku publicznego, które w 2013 r. otrzymały 1\% należnego podatku za 2012 r., znalazło się 7110 podmiotów. W oparciu o kryterium wielkości przysporzenia listę otwiera Fundacja Dzieciom Zdążyć z Pomocą, która jest zdecydowanym liderem skuteczności zabiegania o przychylność i uznanie podatników dokonujących wskazania. W roku 2013 uzyskała ponad 117 mln zł, wyprzedzając drugi w kolejności podmiot o ponad 111 mln zł. Na liście jest 65 organizacji, które w roku 2013 uzyskały ponad milion zł, co kontrastuje z grupą 977 organizacji, które otrzymały mniej niż tysiąc zł.

$\mathrm{W}$ tabeli nr 1 przedstawiono zestawienie dziesięciu organizacji pożytku publicznego, które uzyskały największe przysporzenia w ramach udziału w podatku dochodowym od osób fizycznych w roku 2013.

Tabela 1. Organizacje pożytku publicznego, które otrzymały najwięcej środków w ramach instytucji 1\% w roku 2013

\begin{tabular}{|r|l|c|}
\hline \multicolumn{1}{|c|}{ Lp. } & \multicolumn{1}{|c|}{ Nazwa organizacji } & Kwota w tys. zł \\
\hline 1. & Fundacja Dzieciom Zdążyć z Pomocą & 117183 \\
\hline 2. & Fundacja Pomocy Osobom Niepełnosprawnym Słoneczko & 15329 \\
\hline 3. & Avalon - Bezpośrednia Pomoc Niepełnosprawnym & 8556 \\
\hline 4. & Fundacja Rosa & 8065 \\
\hline 5. & Fundacja Anny Dymnej Mimo Wszystko & 6225 \\
\hline 6. & Dolnośląska Fundacja Rozwoju Ochrony Zdrowia & 5922 \\
\hline 7. & $\begin{array}{l}\text { Stowarzyszenie Rodziców na rzecz Pomocy Szkołom Przyja- } \\
\text { zna Szkoła }\end{array}$ & 4789 \\
\hline 8. & Fundacja Studencka Młodzi - Młodym & 4780 \\
\hline
\end{tabular}

25 Informacja dotyczq̨ca kwot 1\% należnego podatku dochodowego od osób fizycznych przekazanych organizacjom pożytku publicznego z rozliczenia za rok 2012, Departament Podatków Dochodowych Ministerstwa Finansów, Warszawa 2013, http://finanse.mf.gov.pl (dostęp: 25 lutego 2014 r.). 


\begin{tabular}{|r|l|c|}
\hline 9. & Fundacja TVN Nie Jesteś Sam & 4705 \\
\hline 10. & Polskie Towarzystwo Stwardnienia Rozsianego & 4617 \\
\hline
\end{tabular}

Źródło: Departament Podatków Dochodowych Ministerstwa Finansów, Warszawa 2013, http://www.mf.gov.pl.

Rok 2013 był rekordowy z uwagi na wysokość dokonywanych odpisów od należnego podatku. W roku 2004 będącym pierwszym rokiem obowiązywania regulacji w zakresie przekazywania organizacjom pożytku publicznego 1\% należnego podatku dochodowego od osób fizycznych jedynie 80 tys. podatników ogółem przekazało kwotę w wysokości 10,4 $\mathrm{mln}$ zł, co stanowiło $0,03 \%$ podatku należnego. W kolejnym roku obowiązywania regulacji odpisu $1 \%$ dokonało ponad 680 tys. podatników, a kwota przekazana organizacjom wyniosła ok. 41,6 mln zł, co stanowiło 0,14\% podatku należnego. W ostatnich latach wzrasta popularność dokonywania przysporzeń na rzecz organizacji pożytku publicznego, co obrazuje poniższa tabela.

Tabela 2. Instytucja $1 \%$ w organizacjach pożytku publicznego w latach 2004-2013

\begin{tabular}{|c|c|c|}
\hline Rok & $\begin{array}{c}\text { Liczba podatników przekazujących 1\% } \\
\text { należnego podatku na rzecz OPP }\end{array}$ & $\begin{array}{c}\text { Kwota przekazana na } \\
\text { rzecz OPP (w mln zł) }\end{array}$ \\
\hline 2004 & 80320 & 10,4 \\
\hline 2005 & 680541 & 41,6 \\
\hline 2006 & 1156510 & 62,3 \\
\hline 2007 & 1604142 & 105,4 \\
\hline 2008 & 5134675 & 298,3 \\
\hline 2009 & 7324953 & 381,5 \\
\hline 2010 & 8623928 & 360,9 \\
\hline 2011 & 10134625 & 403,9 \\
\hline 2012 & 11165578 & 459,4 \\
\hline 2013 & 11537414 & 480,0 \\
\hline
\end{tabular}

Źródło: Departament Podatków Dochodowych Ministerstwa Finansów, Warszawa 2013, http://www.mf.gov.pl. 
Zdecydowany wzrost kwoty oraz liczby podatników można zaobserwować w roku 2008 r. Było to następstwem uproszczenia procedury przekazywania $1 \%$ podatku należnego w postacie wprowadzenia obowiązujących zasad i odejścia od mechanizmu samodzielnych wpłat od i przez podatników.

\section{Uwagi końcowe}

Udział organizacji pożytku publicznego w podatku dochodowym od osób fizycznych ma charakter fakultatywny, jego materializacja zależy od woli podatnika. Wykonanie ustawowego uprawnienia podatnika do decydowania o przeznaczeniu części podatku dochodowego poprzez wskazanie beneficjenta skutkuje transferem ułamka podatku z budżetu państwa na rzecz wskazanej przez podatnika organizacji pożytku publicznego. Jego konsekwencją jest zmniejszenie dochodów budżetu państwa i odpowiednich, ze względu na miejsce zamieszkania podatnika, budżetów jednostek samorządu terytorialnego, a także utrata przez centralne i samorządowe organy władzy publicznej wpływu na przeznaczenie środków finansowych podlegających przedmiotowej alokacji. Niemniej ogólny cel przeznaczenia środków składających się na 1\% podatku oraz rodzaj podmiotów uprawnionych do ich uzyskania wyznaczają normy ustawy o działalności pożytku publicznego, które dopuszczają przekazywanie 1\% należnego podatku tylko organizacjom pożytku publicznego, a więc podmiotom realizującym zadania wyłącznie o charakterze publicznym. Trafnie takowy transfer środków publicznych został scharakteryzowany w wyroku TK z dnia 13 czerwca 2006 r., gdzie istotę instytucji 1\% skorelowano z wolą polityczną podatnika, która dotyczy skonkretyzowania sposobu przeznaczenia tej części środków publicznych, które pochodzącą od niego. Przeznaczenie części podatku na cele społeczne, aprobowane przez ustawodawcę w granicach określonych przez ustawę, powoduje, że środki wydane na ten cel traktowane są na równi z zapłaconą (w tej części oczywiście) kwotą podatku. W tym znaczeniu stają się sui generis środkami publicznymi lub co najmniej z nimi zrównanymi. TK w wydanym wyroku wyraził ponadto opinię, że tego rodzaju swoboda decyzyjna zawsze musi 
być traktowana jako wyjątek od zasad ogólnego przeznaczenia danin (art. 84 w związku z art. 219 Konstytucji) oraz zarządzania środkami publicznymi w sposób pośredni przez uprawnione władze publiczne.

Udział organizacji pożytku publicznego w podatku nie stanowi typowego elementu konstrukcji podatku, nie wpływa na jego wielkość, jest bowiem następstwem podatku już obliczonego. Majątek osoby wnioskującej o przekazanie $1 \%$ nie podlega $\mathrm{z}$ tego tytułu uszczupleniu ani też powiększeniu. Instytucja $1 \%$ stanowi całkowicie odrębną konstrukcję w stosunku do ulgi podatkowej, która polega na ograniczeniu wielkości obciążenia podatkowego ${ }^{26}$. Możliwości przekazania części podatku nie należy zatem mylić z prawem do odliczania od dochodu części darowizn, będącym w istocie szczególną formą ulgi podatkowej ${ }^{27}$.

Instytucja 1\% oprócz znaczenia finansowego ma także wymiar społeczny, obywatelski bowiem kształtuje $\mathrm{w}$ podatniku poczucie troski i współodpowiedzialności za społeczeństwo oraz kierunki wydatkowania środków publicznych. Podatnik może bezpośrednio przy użyciu swego podatku współuczestniczyć w realizowaniu zadań publicznych, z których skutkami chce się utożsamiać.

\section{Bibliografia:}

Arczewska M., Test na filantropię, czyli 1\% w polskim wykonaniu, „Trzeci Sektor" 2006, nr 7.

Brzeziński B., Prawo podatkowe, TNOiK, Toruń 2000.

Ceglarski A., Organizacje pożytku publicznego, LexisNexis, Warszawa 2005.

Hadzi-Miceva K., Prawne i instytucjonalne mechanizmy wspótpracy organizacji pozarzq̨dowych i administracji państwowej w Chorwacji, Estonii i na Węgrzech. [w:] M. Rymsza (red.) Organizacje pozarzq̨dowe. Dialog Obywatelski. Polityka Państwa, Instytut Spraw Publicznych, Warszawa 2008.

Kurleto M.H., Organizacje pozarzq̨dowe $w$ działalności pożytku publicznego, LexisNexis, Warszawa 2008.

26 Szerzej o ulgach podatkowych: B. Brzeziński, Prawo podatkowe, Toruń 2000, s. 37.

7 A. Huchla, Ustawa o działalności pożytku publicznego i o wolontariacie. Komentarz, Warszawa 2008, s. 115. 
Udział organizacji pożytku publicznego w podatku dochodowym...

Huchla A., Ustawa o działalności pożytku publicznego i o wolontariacie. Komentarz, Wolters Kluwer, Warszawa 2008.

Kopyra J., Ustawa o działalności pożytku publicznego i wolontariacie. Komentarz, C.H. Beck, Warszawa 2005. 